\title{
Community-Acquired Pneumonia in the Childhood: Analysis of the Diagnostic Methods
}

\author{
Henry I. Z. Requejo \\ Adolfo Lutz Institute; São Paulo, SP, Brazil
}

\begin{abstract}
Immunological assays such as CIE, LA, and Dot-ELISA were compared in order to diagnose community-acquired pneumonia. Serum, pleural fluid and urine samples were comparatively employed for bacterial antigen detection. Dot-ELISA proved to be an original and practical alternative procedure for detecting bacterial polysaccharide antigens from pleural fluid and/or concentrated urine samples, providing a rapid diagnosis for pediatric patients with community-acquired pneumonia.

Key-Words: Community-acquired pneumonia, Streptococcus pneumoniae, Haemophilus influenzae, bacterial pneumonia, immunological methods.
\end{abstract}

Community-acquired pneumonias (CAP) are associated with elevated rates of morbidity and mortality. Worldwide, about 4.5 million children younger than 5 years old are yearly affected by acute respiratory infections, and $80 \%$ to $90 \%$ of these cases are pneumonia [1]. Pneumonia has been defined as the presence of fever, acute respiratory symptoms, or both, plus evidence of parenchymal infiltrates on chest radiography. Even this definition overlaps somewhat with that of viral bronchiolitis and leaves some room for disagreement among clinicians [2]. About $80 \%$ of all patients with CAP are treated in an ambulatory setting, most of them without any diagnostic testing, which makes it harder to know the true etiology of pneumonia affecting these patients [3]. However, clinical and laboratory diagnosis using bacterial culture from blood, pleural fluid and pulmonary aspirate has showed that Streptococcus pneumoniae, Haemophilus influenzae type b, Staphylococcus aureus and Mycoplasma pneumoniae are the main etiological agents of the pneumonias. Bacterial cultures of the nasopharynx or throat correlate poorly with cultures of lung tissue and confound more than clarify the etiology. Culture of blood or pleural fluid is clearly an insensitive method, but there are yet any established alternatives in children. Immunological assays have been employed to detect bacterial antigens of S. pneumoniae and/ or $H$. influenzae type $\mathrm{b}$, the most common bacteria causing pneumonia. The polysaccharide antigens have been detected in serum, urine, and/or pleural fluid samples from infants and children with suspected bacterial pneumonia [4-8].

\section{Materials and Methods}

Paired samples of pleural fluid, serum and urine from 550 children with clinical diagnosis of bacterial pneumonia were assayed by counterimmunoelectrophoresis (CIE), latex agglutination (LA), and dot-enzyme-linked immunosorbent assay (Dot-ELISA) for antigen detection according to

Received on 20 September 2006; revised 24 March 2007.

Address for correspondence: Dr. Henry I.Z. Requejo. Instituto Adolfo

Lutz. Av. Dr. Arnaldo 355. Zip code: 01246-902, São Paulo, SP, Brazil.

E-mail:hrequejo@uol.com.br.

The Brazilian Journal of Infectious Diseases 2007;11(2):246-248. (C) 2007 by The Brazilian Journal of Infectious Diseases and Contexto Publishing. All rights reserved. previously standardized procedures [4-8]. Anti-Streptococcus pneumoniae omniserum against 90 serotypes (pneumococcal omniserum) from Seruminstitut, Copenhagen, Denmark [9] and anti-Haemophilus influenzae type b produced according to routine procedure [10] were employed in the immunological methods. Aliquotes of $200 \mu \mathrm{L}$ of pleural fluid and/or serum samples were heat-treated $\left(100^{\circ} \mathrm{C} / 10 \mathrm{~min}\right)$ with $300 \mu \mathrm{L}$ of $0.1 \mathrm{M}$ sodium EDTApH 7.5, followed by centrifugation (2,500 rpm/ $15 \mathrm{~min}$ ), and the supernatant was used in the immunological tests. Pleural fluid samples were also submitted to bacterial culture [4]. Urine samples were left to stand overnight $\left(4^{\circ} \mathrm{C}\right)$ with ethanol (v:v) and centrifugated at 4,000 rpm/15 min for polysaccharide antigen precipitation. The pellet was dissolved in $0.5 \mathrm{~mL}$ of sterile distilled water plus $0.5 \mathrm{~mL}$ of 0.1 M sodium EDTA pH 7.5, followed by heat-treatment (waterbath, $\left.100^{\circ} \mathrm{C} / 10 \mathrm{~min}\right)$. After new centrifugation $(2,500 \mathrm{rpm} / 15$ $\min )$, the supernatant was stored until use in the immunological tests [4-8].

Parametric levels for evaluation of CIE, LA and Dot-ELISA in the use of pleural fluid, serum and urine samples were calculated according to standard method [11].

\section{Results}

Of the 550 pleural fluid samples, 146 (26.5\%) had positive bacterial culture results for $S$. pneumoniae (15.4\%) and $H$. influenzae (11.1\%). Positivities for CIE, LA, and Dot-ELISA, using the same pleural fluid samples, were $36.0 \%, 50.2 \%$, and 63.7\%, respectively. Positivities (S. pneumoniae plus $H$. influenzae) obtained with serum samples in CIE, LA and DotELISA were $24.2 \%, 38.2 \%$, and $58.6 \%$, respectively, while with urine samples the values of $37.0 \%, 47.3 \%$ and $58.0 \%$, respectively, were obtained (Table 1 ).

Parametric levels of sensitivity, specificity, positive (+PV) and negative (-PV) predictive values, prevalence and accuracy for CIE, LA, and Dot-ELISA using pleural fluid, serum and urine samples obtained in relation to the gold standard bacterial cultures of the pleural fluid samples are presented in the Table 2.

\section{Discussion}

Bacterial culture and several immunological assays have been proposed to diagnose community-acquired pneumonia. Bacterial culture of secretions from upper 
Table 1. Comparison among bacterial culture, counterimmunoelectrophoresis (CIE), latex agglutination (LA), and Dot-ELISA for detection of $S$. pneumoniae and $H$. influenzae type b antigens in the 550 paired samples of pleural fluid, serum and urine

\begin{tabular}{|c|c|c|c|c|c|c|c|c|c|c|}
\hline \multirow{2}{*}{ Antigens } & \multirow{2}{*}{ Culture } & \multicolumn{3}{|c|}{ Pleural fluid } & \multicolumn{3}{|c|}{ Serum } & \multicolumn{3}{|c|}{ Urine } \\
\hline & & $\mathbf{C I E}$ & LA & Dot-ELISA & CIE & LA & Dot-ELISA & CIE & LA & Dot-ELISA \\
\hline $\begin{array}{l}\text { S.pneumoniae } \\
(\%)\end{array}$ & $\begin{array}{c}85 \\
(15.4)\end{array}$ & $\begin{array}{c}120 \\
(21.8)\end{array}$ & $\begin{array}{c}164 \\
(29.8)\end{array}$ & $\begin{array}{c}216 \\
(39.3)\end{array}$ & $\begin{array}{c}76 \\
(13.8)\end{array}$ & $\begin{array}{c}120 \\
(21.8)\end{array}$ & $\begin{array}{c}192 \\
(35.0)\end{array}$ & $\begin{array}{c}119 \\
(21.6)\end{array}$ & $\begin{array}{c}151 \\
(27.5)\end{array}$ & $\begin{array}{c}188 \\
(34.2)\end{array}$ \\
\hline $\begin{array}{l}\text { H. influenzae } \\
\text { (\%) }\end{array}$ & $\begin{array}{c}61 \\
(11.1)\end{array}$ & $\begin{array}{c}78 \\
(14.2)\end{array}$ & $\begin{array}{c}112 \\
(20.4)\end{array}$ & $\begin{array}{c}134 \\
(24.4)\end{array}$ & $\begin{array}{c}57 \\
(10.4)\end{array}$ & $\begin{array}{c}90 \\
(16.4)\end{array}$ & $\begin{array}{c}130 \\
(23.6)\end{array}$ & $\begin{array}{c}84 \\
(15.4)\end{array}$ & $\begin{array}{c}109 \\
(19.8)\end{array}$ & $\begin{array}{c}131 \\
(23.8)\end{array}$ \\
\hline $\begin{array}{l}\text { Negative } \\
\text { (\%) }\end{array}$ & $\begin{array}{c}404 \\
(73.5)\end{array}$ & $\begin{array}{c}352 \\
(64.0)\end{array}$ & $\begin{array}{c}274 \\
(49.8)\end{array}$ & $\begin{array}{c}200 \\
(36.3)\end{array}$ & $\begin{array}{c}417 \\
(75.8)\end{array}$ & $\begin{array}{c}340 \\
(61.8)\end{array}$ & $\begin{array}{c}228 \\
(41.4)\end{array}$ & $\begin{array}{c}347 \\
(63.0)\end{array}$ & $\begin{array}{c}290 \\
(52.7)\end{array}$ & $\begin{array}{c}231 \\
(42.0)\end{array}$ \\
\hline $\begin{array}{l}\text { Total positive } \\
\text { (\%) }\end{array}$ & $\begin{array}{c}146 \\
(26.5)\end{array}$ & $\begin{array}{c}198 \\
(36.0)\end{array}$ & $\begin{array}{c}276 \\
(50.2)\end{array}$ & $\begin{array}{c}350 \\
(63.7)\end{array}$ & $\begin{array}{c}133 \\
(24.2)\end{array}$ & $\begin{array}{c}210 \\
(38.2)\end{array}$ & $\begin{array}{c}322 \\
(58.6)\end{array}$ & $\begin{array}{c}203 \\
(37.0)\end{array}$ & $\begin{array}{c}260 \\
(47.3)\end{array}$ & $\begin{array}{c}319 \\
(58.0)\end{array}$ \\
\hline
\end{tabular}

Table 2. Parametric levels for counterimmunoelectrophoresis (CIE), latex agglutination (LA) and Dot-ELISA of pleural fluid, serum and urine samples in relation to bacterial cultures of 550 pleural fluid samples

\begin{tabular}{|c|c|c|c|c|c|c|c|c|c|}
\hline \multirow{2}{*}{ Parameters } & \multicolumn{3}{|c|}{ Pleural fluid } & \multicolumn{3}{|c|}{ Serum } & \multicolumn{3}{|c|}{ Urine } \\
\hline & CIE & LA & Dot-ELISA & CIE & LA & Dot-ELISA & CIE & LA & Dot-ELISA \\
\hline Sensitivity & 100.0 & 100.0 & 100.0 & 91.1 & 100.0 & 100.0 & 100.0 & 100.0 & 100.0 \\
\hline Specificity & 87.1 & 67.8 & 49.5 & 100.0 & 84.2 & 56.4 & 86.0 & 71.8 & 57.2 \\
\hline$+\mathrm{PV}$ & 73.7 & 53.0 & 41.7 & 100.0 & 69.5 & 45.3 & 72.0 & 56.2 & 45.8 \\
\hline -PV & 100.0 & 100.0 & 100.0 & 96.8 & 100.0 & 100.0 & 100.0 & 100.0 & 100.0 \\
\hline Prevalence & 26.5 & 26.5 & 26.5 & 26.5 & 26.5 & 26.5 & 26.5 & 26.5 & 26.5 \\
\hline Accuracy & 90.6 & 76.4 & 63.0 & 97.6 & 88.4 & 68.0 & 89.6 & 79.3 & 68.5 \\
\hline
\end{tabular}

(+PV) positive, and (-PV) negative predictive values.

respiratory tract is not recommended since the normal flora includes the bacteria commonly responsible for pneumonia [2]. On the other hand, blood bacterial culture proved to be a low-sensitive test that depends on viable microorganisms and on previous administration of antimicrobial agents [12]. Other microbiological method named polymerase chain reaction (PCR) has been proposed to diagnose CAP [13]. However, this technique is complex and time-consuming, it has not been yet fully standardized, and is very expensive for use in developing countries. Then, immunological assays such as CIE, LA and Dot-ELISA have been proposed as sensitive and specific methods in the diagnosis of CAP. Studies with CIE and LA have demonstrated that these methods may detect 20 to $50 \mathrm{ng} / \mathrm{mL}$ of polysaccharide bacterial antigens, while enzymatic immunoassays may detect 0.3 to $0.6 \mathrm{ng} / \mathrm{mL}$ [14]. Moreover, among these three methods, CIE is very expensive for developing countries due to the elevated cost of concentrated pneumococcal omniserum, and LA is also difficult to access due to elevated cost of commercial kits.

Our proposed Dot-ELISA proved to be a practical alternative procedure for bacterial antigen detection, in view of its execution without the need for reading equipment, and economy of pneumococcal omniserum and other bacterial antiserum, that may be used at 1:200 dilution [6-8]. Positivities obtained by Dot-ELISA are higher than that obtained by CIE and LA, when pleural fluid, serum, and/or urine samples are employed in the tests, despite the similar values of sensitivity.
Dot-ELISA proved to be an original and practical alternative procedure for detecting bacterial polysaccharide antigens from pleural fluid, serum, and/or concentrated urine samples, providing a rapid diagnosis for pediatric patients with community-acquired pneumonia.

\section{References}

1. Benguigui Y. Infecções respiratórias agudas nas Américas, um problema de saúde pública em transição: da morbimortalidade à resistência antimicrobiana. Bol Pneumol Sanit 2003;11(1):63-75.

2. McIntosh K. Community-acquired pneumonia in children. $\mathrm{N}$ Engl J Med 2002; 346:429-37.

3. Niederman M.S., McCrombs J.L., Unger A.N., et al. The cost of treating community-acquired pneumonia. Clin Ther 1998; 20:820-37.

4. Requejo H.I.Z., Matsumoto T.K., Lotufo J.P.B., et al. Detection of bacterial antigens in acute pneumonia: methods for preparing the urine, serum and pleural fluid samples for the immunological assays. Rev Hosp Clín Fac Med SP 1991;46:19-25.

5. Requejo H.I.Z., Nascimento C.M.P.C., Farhat C.K. Comparison of counterimmunoelectrophoresis, latex agglutination and bacterial culture for the diagnosis of bacterial meningitis using urine, serum and cerebrospinal fluid samples. Braz J Med Biol Res 1992;25:357-67.

6. Requejo H.I.Z., Alkmin M.G.A., Almeida R.G., et al. DotEnzyme-linked immunosorbent assay (Dot-ELISA) for detection of pneumococcal polysaccharide antigens in pleural fluid effusion samples. Comparison with bacterial culture, counterimmunoelectrophoresis and latex agglutination. Rev Inst Med Trop SP 1994:36:531-7.

7. Requejo H.I.Z., Guerra M.L.L., Santos M., Cocozza A.M. Immunodiagnoses of community-acquired pneumonia in childhood. J. Trop. Pediatrics, 1997; 43:208-12. 
8. Requejo H.I.Z., Cocozza A.M. C-Reactive protein in the diagnosis of community-acquired pneumonia. Braz J Infect Dis 2003;7(4):241-4.

9. Kauffmann F., Morch E., Schmith K. On the serology of the pneumococcus-group. J Immunol 1940;39:387-426.

10. Egan W.M., Tsui F.P., Zon G. Structural studies of the Haemophilus influenzae capsular polysaccharides. In: Haemophilus influenzae. Epidemiology, Immunology and Prevention of Diseases. Sell SH, Wright PE eds., Elsevier Pub. Co., 1982, p.185-96.

11. Fletcher R.M., Fletcher S.W., Wagner E.H. Clinical Epidemiology, the Essentials. Baltimore, Waverly, 1983.
12. Feldman W.E. Effect of prior antibiotic therapy on concentrations of bacteria in CSF. Am J Dis Child 1978;132:672-4.

13. Lorente L., Falquera M., Nogués A., et al. Diagnosis of pneumococcal pneumonia by polymerase chain reaction (PCR) in whole blood: a prospective clinical study. Thorax 2000;55:133-7.

14. Macone A.B., Arakere G., Letourneau J.M., Goldmann D.A. Comparison of a new, rapid enzyme-linked immunosorbent assay with latex particle agglutination for the detection of Haemophilus influenzae infection. J Clin Microbiol 1985;21:711-4. 